\title{
Modeling of Spinel Settling in Waste Glass Melter
}

(Project Number: 65422)

\section{Principal Investigator}

Pavel Hrma

Pacific Northwest National Laboratory

P.O. Box 999, MSIN K6-24

Richland, WA 99352

(509) 3765072 (phone)

pavel.hrma@pnl.gov

\section{Co-Investigators}

Petr Schill

Glass Service, Ltd.

Vsetin, Czech Republic

420-657-611-439

research@gsl.cz

Lubomir Nemec

Institute of Inorganic Chemistry

Czech Academy of Sciences

Prague, Czech Republic

420-2-24-310-371

nemec@uach.iic.cas.cz

Jaroslav Klouzek, Institute of Chemical Technology, Prague, Czech Republic Martin Mika, Institute of Chemical Technology, Prague, Czech Republic

Jiri Brada, Glass Service, Ltd., Vsetin, Czech Republic 


\section{Problem Addressed}

The acceptance criteria for high-level waste (HLW) glass allow a substantially higher waste loading than current melters can handle. The particular processing constraint that limits waste loading is the requirement that the liquidus temperature of HLW glass should be lower than $1050^{\circ} \mathrm{C}$ to avoid melter failure due to an excessive settling of spinel. ${ }^{(a)}$ However, this ad hoc requirement, which is not based on a rigorous assessment of the safe rate of solid material (mainly spinel) deposition in the melter, is costly. Each 1 mass\% decrease in waste loading at Hanford will cost DOE approximately $\$ 600,000,000$. Fortunately, waste loading could potentially be increased by several percent even with the currently used melters without producing an unacceptable risk to melter performance. The acceptable fraction of spinel in molten glass depends on several factors, such as the size and number density of spinel crystals, the temperature and velocity fields in the melter, and the spinel sludge rheology.

\section{Research Objective}

Our objective is to determine the fraction and size of spinel crystals in molten HLW glass that are compatible with low-risk melter operation. To this end, we are investigating spinel behavior in HLW glass and obtaining data to be used in a mathematical model for spinel settling in a HLW glass melter. We will modify the current glass-furnace model to incorporate spinelconcentration distribution and to predict the rate of spinel settling. Also, we will determine the nucleation agents that control the number density and size of spinel crystals in HLW glass.

\section{Research Progress}

We have studied the following aspects of spinel behavior in HLW glass:

- spinel formation during the initial melting stages

- the rates of dissolution and crystallization of spinel as a function of temperature

- the equilibrium concentration of spinel as a function of temperature, oxygen partial pressure, and glass composition

- the composition of spinel as a function of temperature

- the effect of temperature history and minor components on the number density and the size of spinel crystals

- the rate and mode of spinel settling

(a) Spinel are compounds having the general structure $\mathrm{M}^{\mathrm{II}} \mathrm{M}^{\mathrm{III}} \mathrm{O}_{4}$. 
- the rheological properties of spinel sludge in molten glass

- the physical characteristics of the spinel-glass system.

Additionally, we have developed

- a mathematical model describing the electric, temperature, and velocity fields in an HLW melter

- a mathematical model of spinel settling in a limited volume of melt

- a physical model to verify the results of the mathematical models.

These results have been reported in the form of publications in conference proceedings and peer-reviewed journals (see the list below). Some major achievements are described below.

The first spinel crystals form during the initial melting stages, precipitating from the nitrate melt within the bed of reacting melter feed. Spinel formation peaks when the nitrate decomposition is nearly complete and the glass-forming melt is established. These crystals, which do not contain $\mathrm{Cr}$, dissolve in the glass-forming melt during the final stages of conversion. $\mathrm{Cr}$ containing spinel forms when the temperature of molten glass drops below the liquidus temperature.

As the melter model shows, the temperature history of the melt in the HLW glass melter is rather wild. A spinel crystal may undergo several cycles of partial dissolution and growth before reaching its final destination, either in the glass canister or at the melter bottom.

The number density of spinel crystals depends on the presence of minor components, such as $\mathrm{RuO}_{2}, \mathrm{Ag}_{2} \mathrm{O}$, or $\mathrm{TiO}_{2}$, and may vary from 1 to $10^{4}$ crystals per $\mathrm{mm}^{3}$. As a result, spinel crystal size may vary from 1 to $100 \mu \mathrm{m}$. The size of spinel crystals is the key factor determining the settling rate.

Laboratory studies of spinel formation must simulate melter conditions (in solid glass that has been powdered before heat treatment, spinel crystallization is affected by low-temperature nucleation and surface crystallization).

The rates of crystal growth and dissolution depend on melt temperature and on the crystal number density, which in turn is determined by the presence of heterogeneous nuclei provided by some minor waste components. Above liquidus temperature, when crystals move within the melt by buoyancy, the rate of dissolution of spinel crystals is constant at constant temperature. The size of growing crystals can be approximated by an exponential function of time with the rate coefficient that is an Arrhenius function of temperature. 
The concentration of spinel in the melt depends on melt temperature, composition, and oxygen fugacity. These functions were expressed in the form of constitutive equations to be used in mathematical models of HLW glass melters and in models for glass formulation, waste retrieval, blending, and pretreatment.

\section{Planned Activities}

- Study the effects of nucleation agents on crystal size and settling rate.

- Develop a theoretical model for dissolution/growth of spinel crystals under nonisothermal conditions.

- Study the dissolution/growth of spinel crystals in periodically increasing and decreasing temperature.

- Compute spinel distribution within the melter and calculate the rate of growth of the spinel sludge bottom layer using the following step-by-step approach:

- Step 1: Spinel crystals enter the melt from the cold cap. Crystals do not change during the process.

- Step 2: Spinel is at equilibrium with molten glass.

- Step 3: Melt redox is a function of temperature. Oxygen bubbles evolve as the temperature of glass increases. Bubbles affect melt density, influencing the temperature and velocity fields.

- Step 4: Spinel crystals dissolve and grow out of equilibrium in response to temperature and redox.

- Step 5: Bubble motion and spinel settling produce cellular convection in a melt; spinel may agglomerate.

- Step 6: Simulate melter conditions for West Valley and Savannah River melters. Compare sludge-thickness calculation with measured values.

\section{Information Access}

The following papers have been published or are in the process of publication:

Hrma P. 1999. "Modeling of spinel settling in waste glass melter." In Science to Support DOE Site Cleanup." PNNL-12208, Pacific Northwest National Laboratory, Richland, Washington.

Hrma P, JD Vienna, JV Crum, GF Piepel, and M Mika. 2000. "Liquidus temperature of high-level waste borosilicate glasses with spinel primary phase." Proc. Mat. Res. Soc.

Izak P, P Hrma, and MJ Schweiger. 2000. "Nonisothermal crystallization of spinel from a high-level waste feed." Proceedings of American Chemical Society. 
Izak P, J Klouzek, and P Hrma. 2000. "Evolution of crystalline phases during high-level waste feed-to-glass conversion." To appear in Ceramic Transactions.

Izak P, P Hrma, JD Vienna, and B Wilson. 2000. "Effect of Oxygen Partial Pressure on liquidus temperature with spinel primary phase." To appear in Ceramic Transactions.

Klouzek J, J Alton, TJ Plaisted, and P Hrma. 2000. "Crucible study of spinel settling in highlevel waste glass." To appear in Ceramic Transactions.

Klouzek J and A Franek. 2000. "Physical and mathematical modeling of spinel settling in high-level waste glass." Proceedings of Waste Management 2000, Tucson, Arizona.

Mika M, JV Crum, and P Hrma. 1999. "Spinel precipitation in high-level waste glass." Proceedings of the 5th ESG Conference, Prague, Czech Republic.

Mika M, P Hrma, and MJ Schweiger. 2000. "Rheology of spinel sludge in molten glass." Ceramics-Silikaty.

Plaisted TJ, J Alton, P Hrma, and B Wilson. 2000. "Spinel nucleation and growth in high-level waste glass." To appear in Ceramic Transactions.

Plaisted TJ, F Mo, B Wilson, and P Hrma. 2000. "Surface crystallization of spinel and acmite in high-level waste glass." To appear in Ceramic Transactions.

Schill P and P Vlcek. June 1999. "Mathematical model of radioactive waste glass melter." Proceedings of the Fifth International Seminar on Mathematical Simulation in Glass Melting, pp.112-118. Horni Becva, Czech Republic.

Schill P, A Franek, M Trochta, P Viktorin, and P Vlcek. June 1999. "Integrated glass furnace model." Proceedings of the Fifth International Seminar on Mathematical Simulation in Glass Melting, pp. 125-137. Horni Becva, Czech Republic.

Stachnik MW, P Hrma, and H Li. 1999. "Effects of high-level waste glass composition on spinel precipitation." Ceram. Trans. 107. 